\title{
ПОТРЕБА ПРАЦІВНИКІВ ЗАВОДУ «ДНІПРОСПЕЦСТАЛЬ» В СТОМАТОЛОГІЧНІЙ ОРТОПЕДИЧНІЙ ДОПОМОЗІ
}

\author{
${ }^{1}$ Д3 «Дніпропетровська медична академія МОз України», м. Дніпро, Україна \\ Запорізький державний медичний університет, м. Запоріжжя, Україна
}

\begin{abstract}
Мета: вивчити потенційну потребу в ортопедичному лікуванні, види зубних протезів та забезпечення працівників заводу «Дніпроспецсталь» стоматологічною ортопедичною допомогою.

Матеріали і методи. Оглянуто 913 працівників: 675 (73,9 \%) чоловіків та 238 (26,1 \%) жінок. Усіх обстежених поділено на чотири вікові групи.

Результати. У віці 21-30 років потреба у ортопедичному лікуванні серед обстеженого контингенту в середньому складає $(73,9 \pm 0,35) \%$, 31-40 років - $(85,3 \pm 0,47) \%$ та сягає $100 \%$ у віковій групі 41-50 років. Загалом потребують ортопедичного лікування $(91,1 \pm 0,06) \%$ обстежених $((96,2 \pm 0,04) \%$ чоловіків та $(88,5 \pm 0,08) \%$ жінок).

За даними обстеження, серед працівників заводу повністю забезпечені зубними протезами 37,1 \%, частково забезпечені та потребують додаткового протезування - 33,7 \%. Частка працівників, які мають потребу в протезуванні, $-29,2 \%$.

Відсоток працівників, які повністю забезпечені зубними протезами, з віком збільшується з 30,7 \% у віковій групі 31-40 років до 58,2 \% у віці 51-60 років. Відсоток обстежених, які мають зубні протези, але потребують додаткового лікування, сягає максимальних значень у віці 41-50 років, мінімальних - у віковій групі 51-60 років. У жінок ці показники в кожній віковій групі більші, ніж у чоловіків ( $p<0,05)$.

Частка працівників, які не мають зубних протезів, з віком знижується з 69,7 \% у віковій групі 21-30 років до 18,2 \% у віці 51-60 років.

Потреба обстежених працівників у поодиноких коронках складає $(64,3 \pm 0,35) \%$, в мостоподібних протезах $(66,0 \pm 0,34) \%$, у часткових знімних протезах - $(25,0 \pm 0,15) \%$, в повних знімних протезах - $(7,7 \pm 0,53) \%$.

Висновки. За даними обстеження, потребують ортопедичного лікування $(91,1 \pm 0,06) \%$ обстежених працівників заводу. Повністю забезпечені зубними протезами 37,1 \%, частково забезпечені - 33,7 \%, а 29,2 \% працівників мають абсолютну потребу в протезуванні.

Обстежені у віці 20-40 років потребують лікування незнімними зубними протезами, у віці 41-50 років комбінованими зубними протезами, а працівники у віці 51-60 років потребують відновлення цілісності зубних рядів знімними пластинковими протезами.
\end{abstract}

КЛЮчОВІ СЛОВА: стоматологічна ортопедична допомога; забезпечення; потреба.

Питома вага стоматологічних захворювань серед загальної захворюваності населення за зверненнями сягає 20-25\% (третє місце), що свідчить про високу потребу населення в цьому виді медичної допомоги [3, 4, 6].

За даними ВОО3, часткова відсутність зубів, поряд із карієсом та хворобами пародонта, належить до найрозповсюдженішої патології зубощелепної системи. Від неї страждають до 75 \% населення в різних регіонах земної кулі. При цьому збільшення розповсюдженості захворювання та кількість відсутніх зубів помітно зростає в старших вікових групах [5, 7-9].

Ортопедична стоматологія $є$ однією 3 наймасовіших видів медичної допомоги. Потреба населення нашої країни в зубному протезуванні коливається в межах 60-100 \% в різних вікових групах. Необхідність протезування більша у чоловіків, але при цьому жінки частіше потребують незнімних, а чоловіки - знімних видів ортопедичних конструкцій $[1,2,6]$.

(с) А. В. Самойленко, І. В. Возна, 2019
Варто зауважити, що останнім часом все більше спостерігають невідповідність між попитом та потребою в цьому виді спеціалізованої медичної допомоги. Потреба дорослого населення в зубопротезуванні задовольняється не більше ніж на 8-10\% [2-4].

Територіальні особливості стану довкілля, умови праці та відсутність профрілактичних програм і заходів впливають на поширеність основних стоматологічних захворювань, що, в свою чергу, впливає на масштаби порушення цілісності зубощелепної системи та потреби в стоматологічній ортопедичній допомозі [5, 8].

Необхідно зазначити, що досліджень, безпосередньо присвячених вивченню потреби в зубному протезуванні працівників заводу «Дніпроспецсталь», до теперішнього часу не проводили.

Мета дослідження: вивчити потенційну потребу в ортопедичному лікуванні, види зубних протезів та забезпечення працівників заводу «Дніпроспецсталь» стоматологічною ортопедичною допомогою. 
Матеріали і методи. Оглянуто 913 працівників заводу «Дніпроспецсталь»: 675 (73,9 \%) чоловіків та 238 (26,1 \%) жінок. Усіх обстежених поділено на чотири вікові групи: перша (21-30 років) - 145; друга (31-40 років) - 270; третя (41-50 років) 278; четверта (51-60 років) - 220 працівників.

Для оцінки стоматологічного статусу використовували Медичну карту обстеження стоматологічного хворого, яку було розроблено на основі карти стоматологічного хворого фрорма 0/43о 3 нашими доповненнями. Дослідження проводили в рамках профрілактичного огляду працівників заводу «Дніпроспецсталь» міста Запоріжжя.

Забезпечення ортопедичними конструкціями виявляли за орактом наявності поодиноких коронок, мостоподібних протезів, їх кількості; комбінованих і часткових пластинкових протезів; повних знімних протезів та їх відсутністю.

Потенційну потребу в стоматологічному ортопедичному лікуванні ми визначали з урахуванням наявності дефектів зубних рядів, патології твердих тканин зубів некаріозного і каріозного процесу та його ускладнень, захворювань тканин пародонта, які потребують протезування. Також ми враховували осіб із деоректами твердих тканин зубів та зубних рядів, що раніше були відновлені ортопедичними конструкціями.

При вивченні потреби працівників в ортопедичному лікуванні враховували якість попереднього протезування, фрункціональний стан тканин пародонта, ступінь тяжкості патологічного процесу, топографію дефекту зубного ряду, кількість відсутніх зубів та стан зубів-антагоністів.

Статистичну обробку матеріалу проводили 3 застосуванням пакета програм Microsoft Office Excel. Достовірними вважали рівень значущості при р<0,05 з надійністю $95 \%$.

Результати дослідження та їх обговорення. Аналізуючи результати дослідження, ми помітили взаємозв'язки між віком і статтю обстежених та рівнем потреби в стоматологічній ортопедичній допомозі. Враховуючи те, що розповсюдженість стоматологічних захворювань, що потребують ортопедичного лікування, дуже висока, тому цей показник доцільно розраховувати на 100 обстежених (табл. 1).

Таблиця 1. Потреба працівників заводу «Дніпроспецсталь» у стоматологічній ортопедичній допомозі залежно від статі та віку (\%)

\begin{tabular}{|c|c|c|c|}
\hline \multirow{2}{*}{ Вікові групи (роки) } & \multicolumn{2}{|c|}{ Стать } & \multirow{2}{*}{ Загалом } \\
\cline { 2 - 3 } & чоловіки & жінки & $73,9 \pm 0,35$ \\
\hline $21-30$ & $77,2 \pm 0,23$ & $67,3 \pm 0,27$ & $85,3 \pm 0,47$ \\
\hline $31-40$ & $96,1 \pm 0,62$ & $81,5 \pm 0,31$ & 100,0 \\
\hline $41-50$ & 100,0 & 100,0 & 100,0 \\
\hline $51-60$ & 100,0 & 100,0 & $91,1 \pm 0,06$ \\
\hline
\end{tabular}

Так, у віці 21-30 років потреба в ортопедичному лікуванні серед обстеженого контингенту в середньому складає $(73,9 \pm 0,35) \%$. Далі кількість працівників, яким потрібні зубні протези, збільшується. У віці 31-40 років потреба в ортопедичному лікуванні становить $(85,3 \pm 0,47) \%$ та сягає $100 \%$ у віковій групі 41-50 років. При цьому в чоловіків вікової групи 21-40 років потреба в зубних протезах значно вища, ніж у жінок $(p<0,05)$. Вирівнювання цих показників відбувається у віковій групі 51-60 років.

Загалом потребують ортопедичного лікування $(91,1 \pm 0,06) \%$ обстежених $((96,2 \pm 0,04) \%$ чоловіків та $(88,5 \pm 0,08) \%$ жінок).

На нашу думку, найбільш повно характеризує потребу в ортопедичному лікуванні необхідність визначення осіб, які потребують зубних протезів, але їх не мають. Осіб, які частково забезпечені зубними протезами, але потребують додаткового протезування, та осіб, які повністю ними забезпечені.

За даними обстеження, серед працівників заводу повністю забезпечені зубними протезами
37,1 \% працівників, частково забезпечені та потребують додаткового протезування - 33,7 \%. Частка працівників, які мають потребу в протезуванні, - 29,2 \%.

Серед обстежених жінок повністю забезпечені зубними протезами - 37,8 \%, частково забезпечені та потребують додаткового протезування - 35,0 \%, потребують зубних протезів, але їх не мають, 27,2 \% працівників. Серед обстежених чоловіків повністю забезпечені зубними протезами - 33,1 \%, частково забезпечені та потребують додаткового протезування - 34,3 \%, потребують зубних протезів, але їх не мають, - 32,6 \% робітників.

Аналізуючи результати дослідження, ми виявили особливості ступеня задоволеної потенційної потреби працівників заводу в стоматологічній ортопедичній допомозі у різних вікових групах.

Так, відсоток працівників, які повністю забезпечені зубними протезами, з віком збільшується 3 30,7 \% у віковій групі 31-40 років до 58,2 \% у віці 51-60 років. Відсоток обстежених, які мають зубні протези, але потребують додаткового лікування, сягає максимальних значень у віці 41-50 років, 
мінімальних - у віковій групі 51-60 років. У жінок ці показники в кожній віковій групі більші, ніж у чоловіків $(p<0,05)$. Це ми можемо пояснити тим, що жінки більш ретельно ставляться до свого стоматологічного здоров'я.

Частка працівників, які не мають зубних протезів, з віком знижується з 69,7 \% у віковій групі 21-30 років до $18,2 \%$ у віці $51-60$ років.

Нас турбує, що в молодій віковій групі особи, які потребують зубного протезування, мають найвищі показники, порівняно зі старшими віковими групами, та немає осіб, які були б повністю забезпечені зубними протезами (табл. 2).

На наш погляд, до значного руйнування зубощелепної системи у старших вікових групах призводить недостатня медична активність населення до стоматологічного ортопедичного лікування. Це пов'язано 3 недостатньою профрілактичною роботою стоматологів та низьким рівнем санітарно-гігієнічних знань працівників заводу.

Таблиця 2. Особливості задоволеної потреби працівників заводу «Дніпроспецсталь» у стоматологічній ортопедичній допомозі залежно від віку та статі (\%)

\begin{tabular}{|c|c|c|c|c|c|}
\hline \multicolumn{2}{|c|}{ Статево-вікові групи } & \multicolumn{3}{|c|}{ Ступінь задоволеної потенційної потреби в ортопедичній допомозі } & \multirow[b]{2}{*}{ Загалом } \\
\hline роки & стать & $\begin{array}{c}\text { повністю задоволена } \\
\text { потреба }\end{array}$ & $\begin{array}{c}\text { частково задоволена } \\
\text { потреба }\end{array}$ & $\begin{array}{c}\text { абсолютна } \\
\text { потреба }\end{array}$ & \\
\hline \multirow[t]{3}{*}{$21-30$} & Чол. & - & 27,2 & 72,8 & 100,0 \\
\hline & Жін. & - & 38,1 & 61,9 & 100,0 \\
\hline & Разом & - & 30,3 & 69,7 & 100,0 \\
\hline \multirow[t]{3}{*}{$31-40$} & Чол. & 27,7 & 26,5 & 45,8 & 100,0 \\
\hline & Жін. & 31,9 & 26,7 & 41,4 & 100,0 \\
\hline & Разом & 30,7 & 26,6 & 42,7 & 100,0 \\
\hline \multirow[t]{3}{*}{$41-50$} & Чол. & 30,6 & 43,6 & 25,8 & 100,0 \\
\hline & Жін. & 34,1 & 45,1 & 20,8 & 100,0 \\
\hline & Разом & 32,6 & 44,1 & 23,3 & 100,0 \\
\hline \multirow[t]{3}{*}{$51-60$} & Чол. & 59,3 & 21,7 & 19,0 & 100,0 \\
\hline & Жін. & 56,6 & 26,3 & 17,1 & 100,0 \\
\hline & Разом & 58,2 & 23,6 & 18,2 & 100,0 \\
\hline \multirow[t]{3}{*}{ Загалом } & Чол. & 33,1 & 34,3 & 32,6 & 100,0 \\
\hline & Жін. & 37,8 & 35,0 & 27,2 & 100,0 \\
\hline & Разом & 37,1 & 33,7 & 29,2 & 100,0 \\
\hline
\end{tabular}

Даних, які висвітлюють розповсюдженість стоматологічних захворювань, що потребують ортопедичного лікування, та загальний рівень необхідності зубного протезування, недостатньо для визначення обсягів потреби в ортопедичній допомозі. На вибір конструкції зубного протеза має вплив збільшення кількості втрачених зубів.

Загалом потреба обстежених працівників у поодиноких коронках складає $(64,3 \pm 0,35) \%$, в мостоподібних протезах - $(66,0 \pm 0,34) \%$, в часткових знімних протезах - $(25,0 \pm 0,15) \%$, в повних знімних протезах - $(7,7 \pm 0,53) \%$.

Серед обстежених жінок потреба в поодиноких коронках становить $(65,2 \pm 0,17) \%$, в мостоподібних протезах - $(68,3 \pm 0,12) \%$, в часткових знімних протезах - $(26,4 \pm 0,01) \%$, в повних знімних протезах - $(7,1 \pm 0,50) \%$, а серед чоловіків потреба в поодиноких коронках складає $(63,0 \pm 0,58) \%$, в мостоподібних протезах - $(62,8 \pm 0,59) \%$, в часткових знімних протезах - $(23,2 \pm 0,26) \%$, в повних знімних протезах - $(8,5 \pm 0,57) \%$ (табл. 3).

У віковій групі 21-30 років потреба працівників у поодиноких коронках складає $(91,6 \pm 0,30) \%$. Ми помітили, що в цій віковій групі вже $(71,8 \pm 0,34)$ \% працюючих потребують лікування мостоподібними протезами та $(8,5 \pm 0,30) \%$ частковими знімними протезами.

3 віком збільшується кількість та ступінь руйнування зубів. Так, у віковій групі 41-50 років потреба в поодиноких коронках різко знижується та становить $(63,9 \pm 0,27) \%$. У старшому віці цей показник складає $(40,6 \pm 0,14) \%(p<0,05)$.

Потреба обстежених працівників у мостоподібних протезах збільшується $3(71,8 \pm 0,34) \%$ у віковій групі 21-30 років та сягає максимальних значень у віці 41-50 років $(90,4 \pm 3,24) \%(p<0,05)$. У працівників вікової групи 51-60 років відбувається зниження цього показника до $(79,7 \pm 5,03) \%$ за рахунок зменшення кількості зубів $(p<0,05)$.

Нас турбує, що в осіб 21-30 років вже $є$ потреба в часткових знімних протезах у $(8,5 \pm 0,30) \%$ випадків. Далі цей показник збільшується у віковій групі 41-50 років $(33,7 \pm 0,19) \%$ та сягає максимальних значень $(45,3 \pm 0,22) \%$ у віковій групі 51-60 років $(p<0,05)$.

На нашу думку, це можна пояснити збільшенням кількості видалених зубів та появою дефектів зубних рядів, відновлення яких можливо комбінованими протезами або частковими знімними протезами. 
Таблиця 3. Поділ працівників, які потребують ортопедичного лікування, залежно від статі, віку та виду конструкцій зубних протезів (\%)

\begin{tabular}{|c|c|c|c|c|c|}
\hline \multicolumn{2}{|c|}{ Статево-вікові групи } & \multicolumn{4}{|c|}{ Основні види ортопедичних конструкцій } \\
\hline $\begin{array}{c}\text { вік } \\
\text { (роки) }\end{array}$ & стать & $\begin{array}{c}\text { поодинокі } \\
\text { коронки }\end{array}$ & $\begin{array}{c}\text { мостоподібні } \\
\text { протези }\end{array}$ & $\begin{array}{c}\text { часткові знімні } \\
\text { протези }\end{array}$ & $\begin{array}{c}\text { повні знімні } \\
\text { протези }\end{array}$ \\
\hline \multirow[t]{3}{*}{$21-30$} & Чол. & $88,0 \pm 0,50$ & $68,0 \pm 0,33$ & $12,0 \pm 0,26$ & - \\
\hline & Жін. & $93,5 \pm 0,64$ & $73,9 \pm 0,47$ & $6,5 \pm 0,36$ & - \\
\hline & Разом & $91,6 \pm 0,30$ & $71,8 \pm 0,34$ & $8,5 \pm 0,30$ & - \\
\hline \multirow[t]{3}{*}{$31-40$} & Чол. & $92,9 \pm 0,97$ & $76,2 \pm 0,57$ & $9,5 \pm 0,65$ & - \\
\hline & Жін. & $89,8 \pm 0,32$ & $75,5 \pm 0,14$ & $6,1 \pm 0,32$ & - \\
\hline & Разом & $91,2 \pm 0,97$ & $75,8 \pm 0,49$ & $7,7 \pm 0,59$ & - \\
\hline \multirow[t]{3}{*}{$41-50$} & Чол. & $59,5 \pm 0,07$ & $86,5 \pm 5,62$ & $27,0 \pm 0,30$ & $6,5 \pm 0,46$ \\
\hline & Жін. & $67,4 \pm 0,91$ & $93,5 \pm 3,64$ & $39,1 \pm 0,20$ & $3,1 \pm 0,23$ \\
\hline & Разом & $63,9 \pm 0,27$ & $90,4 \pm 3,24$ & $33,7 \pm 0,19$ & $4,8 \pm 0,17$ \\
\hline \multirow[t]{3}{*}{$51-60$} & Чол. & $34,5 \pm 0,83$ & $65,5 \pm 8,83$ & $65,5 \pm 0,83$ & $24,4 \pm 0,32$ \\
\hline & Жін. & $45,7 \pm 0,42$ & $91,4 \pm 4,73$ & $28,6 \pm 0,64$ & $9,3 \pm 0,57$ \\
\hline & Разом & $40,6 \pm 0,14$ & $79,7 \pm 5,03$ & $45,3 \pm 0,22$ & $17,1 \pm 0,87$ \\
\hline \multirow[t]{3}{*}{ Загалом } & Чол. & $63,0 \pm 0,58$ & $62,8 \pm 0,59$ & $23,2 \pm 0,26$ & $8,5 \pm 0,57$ \\
\hline & Жін. & $65,2 \pm 0,17$ & $68,3 \pm 0,12$ & $26,4 \pm 0,01$ & $7,1 \pm 0,50$ \\
\hline & Разом & $64,3 \pm 0,35$ & $66,0 \pm 0,34$ & $25,0 \pm 0,15$ & $7,7 \pm 0,53$ \\
\hline
\end{tabular}

Потреба в ортопедичному лікуванні повними знімними протезами на одній або двох щелепах, за нашими даними, складає $(4,8 \pm 0,17) \%$ вже у віковій групі 41-50 років. Зі збільшенням віку цей показник зростає та становить $(17,1 \pm 0,87) \%$ випадків ( $<<0,05)$. Загалом суттєвої різниці потреби в повних знімних протезах у чоловіків та жінок не визначено ( $p>0,05)$.

\section{Висновки}

За даними обстеження, потребують ортопедичного лікування $(91,1 \pm 0,06)$ \% обстежених працівників заводу. Повністю забезпечені зубними протезами 37,1 \%, частково забезпечені - 33,7 \%, а 29,2 \% працівників мають абсолютну потребу в протезуванні.
Обстежені у віці 20-40 років потребують лікування незнімними зубними протезами, у віці 41-50 років - комбінованими зубними протезами, а працівники у віці 51-60 років, у зв'язку з наростаючою втратою зубів за рахунок великої розповсюдженості захворювань тканин пародонта та ускладнень карієсу, потребують відновлення цілісності зубних рядів знімними пластинковими протезами.

Перспективи подальших досліджень будуть спрямовані на вивчення впливу шкідливих фракторів виробництва на рівень потреби працівників у стоматологічній ортопедичній допомозі та розробку методів ранньої діагностики і профрілактики стоматологічних захворювань, що зумовлюють втрату зубів.

\section{Список літератури}

1. Борисенко Л. Г. Сравнительный анализ нуждаемости в ортопедической стоматологической помощи пожилых людей Беларуси, проживающих в разных условиях / Л. Г. Борисенко // БГМУ: 90 лет в авангарде медицинской науки и практики : сб. науч. тр. / М-во здравоохр. Респ. Беларусь, Бел. гос. мед. ун-т ; редкол. : А. В. Сикорский, О. К. Кулага. - Минск : ГУ РНМБ, 2014. - Вып. 4. - С. 28-30.

2. Канюра О. А. Стан стоматологічного здоров'я та потреба в ортопедичній допомозі пацієнтів приватного стоматологічного закладу / О. А. Канюра // Вісник проблем біології і медицини. - 2014. - Т. 2, № 4 (114). - С. $279-280$. 3. Лабунець О. В. Комплексна характеристика стану стоматологічної ортопедичної захворюваності та допомоги у осіб молодого віку / О. В. Лабунець // Інновації в стоматології. - 2014. - № 4. - С. 131-137.

4. Мазур І. П. Сучасний стан стоматологічної допомоги в Україні / І. П. Мазур, О. В. Павленко, В. Г. Близнюк // Медична газета «Здоров'я України 21 сторіччя». - 2017. - № 18 (415).

5. Мірчук Б. М. Частота дефектів зубних рядів серед дорослих пацієнтів м. Запоріжжя, які звернулися за протетичним лікуванням / Б. М. Мірчук, Я. В. Максимов // Актуальні питання фрармацевтичної і медичної науки та практики. 2017. - Т. 10, № 1 (23). - С. 102-106.

6. Муртазина М. А. О структуре стоматологической ортопедической помощи, оказываемой в крупном промышленном городе / М. А. Муртазина, Т. И. Карпунина // Проблемы стоматологии. - 2014. - № 2. - С. 57-59.

7. Науменко К. Є. Розповсюдженість основних стоматологічних захворювань та потреба військовослужбовців в ортопедичному лікуванні (огляд літератури) / К. Є. Науменко, О. Б. Бєліков // Буковинський медичний вісник. 2017. - Т. 21, № 1 (81). - С. 211-213. 
8. Повна втрата зубів. Поширеність. Потреба в ортопедичному лікуванні / М. М. Ватаманюк, О. Б. Бєліков, О. О. Максимов [та ін.] // Буковинський медичний вісник. - 2012. - Т. 16, № 4. - С. 191-195.

9. Распространенность, интенсивность, структура и динамика развития малых включенных дефектов зубных рядов у лиц молодого возраста гг. Ивано-Франковска и Тернополя по данным обращаемости / О. В. Лабунец, О. В. Деньга, В. А. Лабунец [и др.] // Архів клінічної медицини. - 2014. - № 1 (20). - С. 83-86.

\section{References}

1. Borisenko, L.G. (2014). Sravnitelnyy analiz nuzhdaemosti v ortopedicheskoy stomatologicheskoy pomoshchi pozhylykh lyudey Belarusi, prozhivayuschikh v raznykh usloviyakh [Comparative analysis of orthopedic dental care need of elderly people from Belarus living in different conditions]. BSMU: 90 years in the avant-garde of medical science and practice: comp. scien. w. MPH Rep. Belarus, Bel. State Med. Un-ty; ed.board. Minsk: GU RNMB, 4 [in Russian].

2. Kaniura, O.A. (2014). Stan stomatolohichnoho zdorovia ta potreba v ortopedychnii dopomozi patsiientiv pryvatnoho stomatolohichnoho zakladu [The condition of dental health and the patients' orthopedic care at the need in a private dental institution]. Visnyk problem biolohii i medytsyny - Herald of Biology and Medicine Problems, 4, 2 (114), $279-280$ [in Ukrainian].

3. Labunets, O.V. (2014). Kompleksna kharakterystyka stanu stomatolohichnoi ortopedychnoi zakhvoriuvanosti ta dopomohy u osib molodoho viku [Comprehensive characteristic of the dental orthopedic morbidity condition and assistance in young people]. Innovatsii v stomatolohii - Innovations in Dentistry, 4, 131-137 [in Ukrainian].

4. Mazur, I.P., Pavlenko, O.V. \& Blyzniuk, V.H. (2017). Suchasnyi stan stomatolohichnoi dopomohy v Ukraini [Moderate state of dental care in Ukraine]. Medychna hazeta "Zdorovia Ukrainy 21 storichcha" - Medical Newspaper "Health of Ukraine of the 21st century", 18 (415) [in Ukrainian].

5. Mirchuk, B.M. \& Maksimov, Ya.V. (2017). Chastota defektiv zubnykh ryadiv sered doroslykh patsiientiv m. Zaporizhzhia, yaki zvernulysia za protetychnym likuvanniam [Frequency of dentition's defects among adult patients in Zaporizhzhia, who asked for prosthetic treatment]. Aktualni pytannia farmatsevtychnoi i medychnoi nauky ta praktyky - Relevant Issues of Pharmaceutical and Medical Science and Practice, 10, 1 (23), 102-106 [in Ukrainian].

6. Murtazina, M.A. \& Karpunina, T.I. (2014). O strukture stomatologicheskoy ortopedicheskoy pomoshchi, okazyvayemoy v krupnom promyishlennom gorode [On the structure of dental prosthetic care provided in a large industrial city]. Problemy stomatologii - Problems of Dentistry, 2, 57-59 [in Russian].

7. Naumenko, K.Ye. \& Belikov, O.B. (2017). Rozpovsiudzhenist osnovnykh stomatolohichnykh zakhvoriuvan ta potreba viiskovosluzhbovtsiv $v$ ortopedychnomu likuvanni (ohliad literatury) [The prevalence of major dental diseases and the militaries' need in orthopedic treatment (review of literature)]. Bukovynskyi medychnyi visnyk - Bukovyna Medical Herald, 21, 1 (81), 211-213 [in Ukrainian].

8. Vatamaniuk, M.M., Belikov, O.B. \& Maksimov, O.O. (2012). Povna vtrata zubiv. Poshyrenist. Potreba v ortopedychnomu likuvanni [Complete loss of teeth. Prevalence. The need in prosthetic treatment]. Bukovynskyi medychnyi visnyk - Bukovyna Medical Herald, 16, 4, 191-195 [in Ukrainian].

9. Labunets, O.V., Denga, O.V., Labunets, V.A., Dieva, T.V. \& Lepskyy, V.V. (2014). Rasprostranennost, intensivnost, struktura i dinamika razvitiya malykh vklyuchennykh defektov zubnykh ryadov u lits molodogo vozrasta g. Ivano-Frankovska i Ternopolya po dannym obrashchaemosti [Prevalence, intensity, structure and dynamics of small included defects of dentition's development in young people of Ivano-Frankovsk and Ternopil according to appealability]. Arkhiv klinichnoi medytsyny - Archive of Clinical Medicine, 1 (20), 83-86 [in Russian].

\section{ПОТРЕБНОСТЬ РАБОТНИКОВ ЗАВОДА «ДНЕПРОСПЕЦСТАЛЬ» В СТОМАТОЛОГИЧЕСКОЙ ОРТОПЕДИЧЕСКОЙ ПОМОЩИ}

А. В. Самойленко ${ }^{1}$ И. В. Возная

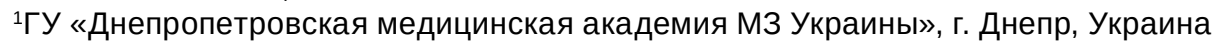

2Запорожский государственный медицинский университет, г. Запорожье, Украина

Цель: изучить потенциальную потребность в ортопедическом лечении, виды зубных протезов и обеспечение работников завода «Днепроспецсталь» стоматологической ортопедической помощью.

Материалы и методы. Осмотрены 913 работников: 675 (73,9 \%) мужчин и 238 (26,1\%) женщин. Всех обследованных распределили на четыре возрастные группы.

Результаты. В возрасте 21-30 лет потребность в ортопедическом лечении среди обследованного контингента в среднем составляет $(73,9 \pm 0,35) \%, 31-40$ лет - $(85,3 \pm 0,47) \%$ и достигает $100 \%$ в возрастной группе 41-50 лет. В целом нуждаются в ортопедическом лечении $((91,1 \pm 0,06) \%$ обследованных $(96,2 \pm 0,04) \%$ мужчин и $(88,5 \pm 0,08) \%$ женщин).

По данным обследования, среди работников завода полностью обеспечены зубными протезами 37,1 \%, частично обеспечены и нуждаются в дополнительном протезировании - 33,7 \%, имеют потребность в протезировании - 29,2\%.

Процент работников, которые полностью обеспечены зубными протезами, с возрастом увеличивается от 30,7 \% в возрастной группе 31-40 лет до 58,2 \% в возрасте 51-60 лет. Процент обследованных, которые имеют зубные протезы, но нуждаются в дополнительном протезировании, достигает максимальных значений в возрасте 41-50 лет, минимальных - в возрастной группе 51-60 лет. У женщин эти показатели в каждой возрастной группе больше, чем у мужчин $(p<0,05)$. 
Часть работников, которые не имеют зубных протезов, с возрастом снижается от 69,7 \% в возрастной группе 21-30 лет до 18,2 \% в возрасте 51-60 лет.

В целом потребность обследованных работников в одиночных коронках составляет $(64,3 \pm 0,35) \%$, в мостовидных протезах - $(66,0 \pm 0,34) \%$, в частичных съемных протезах - $(25,0 \pm 0,15) \%$, в полных съемных протезах - $(7,7 \pm 0,53) \%$.

Выводы. По данным обследования, нуждаются в ортопедическом лечении $(91,1 \pm 0,06) \%$ обследованных работников завода. Полностью обеспечены зубными протезами 37,1 \%, частично обеспечены - 33,7 \%, а 29,2 \% работников имеют абсолютную потребность в протезировании.

Обследованные в возрасте 20-40 лет нуждаются в лечении несъемными зубными протезами, в возрасте 41-50 лет - комбинированными зубными протезами, а работники в возрасте 51-60 лет нуждаются в восстановлении целостности зубных рядов съемными пластиночными протезами.

КЛЮЧЕВЫЕ СЛОВА: стоматологическая ортопедическая помощь; обеспеченность; потребность.

\section{THE NEED OF DNIPROSPETSSTAL PLANT'S STAFF IN PROSTHETIC CARE}

A. V. Samoilenko', I. V. Vozna ${ }^{2}$

${ }^{1}$ Dnipropetrovsk Medical Academy, Dnipro, Ukraine

'Zaporizhzhia State Medical University, Zaporizhzhia, Ukraine

Purpose: to study providing and needs of Dneprospetsstal plant's staff in dental prosthetic care.

Materials and Methods. To achieve the goal of the study, 913 factory workers were examined: 675 (73.9\%) men and 238 (26.1\%) women. All examined were divided into four age groups.

Results. In age of 21-30 a requirement in prosthetic treatment among the inspected contingent makes (73.9 \pm 0.35$) \%$. In age $31-40$ a necessity makes $(85.3 \pm 0.47) \%$ and arrives at $100 \%$ in the age-related group $41-50$. On the whole, need prosthetic treatment of $(91.1 \pm 0.06) \%$ inspected $(96.2 \pm 0.04) \%$ men and $(88.5 \pm 0.08) \%$ women).

From data of our inspection, fully provided with the dentures of $37.1 \%$ workers of plant, partly provided and need additional prosthetic treatment $-33.7 \%$, have a requirement in prosthetic treatment $-29.2 \%$.

Analyzing the results of our research, we have revealed the features of potential necessity of workers of plant in a prosthetic treatment in the different age-related groups.

Percent of workers that is fully provided with dentures, with age increases from $30.7 \%$ in the age-related group 31-40 to $58.2 \%$ in age 51-60. Percent of inspected, that have dentures, but need additional prosthetic treatment, arrives at maximal values in age 41-50 minimum - in the age-related group 51-60. For women these indexes more than for men $(P<0.05)$ in every age-related group.

Part of workers that does not have dentures, with age goes down from $69.7 \%$ in the age-related group 21-30 to $18.2 \%$ in age $51-60$.

On the whole the requirement of the inspected workers in single prosthetic crowns makes $(64.3 \pm 0.35) \%$, in dental bridges - $(66.0 \pm 0.34) \%$, in partial removable dentures - $(25.0 \pm 0.15) \%$, in complete dentures $-(7.7 \pm 0.53) \%$.

Conclusions. Thus, from data of our inspection, $(91.1 \pm 0.06) \%$ of the inspected workers of the plant need prosthetic treatment. Fully provided with the dentures of $37.1 \%$, partly provided $-33.7 \%$, and $29.2 \%$ workers had absolute requirement in prosthetic treatment.

At the age of 21-40 years old they need non-removable dentures, at 41-50 years old - in combined ones, at 51-60 years old - in removable dentures.

KEY WORDS: prosthetic dental treatment; material well-being; necessity.

Рукопис надійшов до редакції 28.02.2019 р.

Відомості про авторів:

Самойленко Андрій Валерійович - доктор медичних наук, профресор, завідувач кафедри терапевтичної стоматології ДЗ «Дніпропетровська медична академія МОЗ України».

Возна Ірина Володимирівна - кандидат медичних наук, доцент кафедри пропедевтичної та хірургічної стоматології Запорізького державного медичного університету; тел.: +38(098) 094-42-75. 